\title{
"Rudali": Men, Women and the Politics of Crying
}

\author{
Saikat Guha \\ Department of English, Cooch Behar Panchanan Barma University, West Bengal. \\ Email:mmm.saikatguha@gmail.com
}

\begin{abstract}
In a compelling narrative, Mahasweta Devi's "Rudali" scrutinises how the traditional image of a crying woman can be subverted against the background of outrageous corruption. Here the women do not cry at their own destitution, but their tears rescue the men from their shame. Engrossed in their lust for property and lacking in emotions, the Rajput men in Chhotanagpur area hire the "rudalis" (professional mourners) to cry at the funeral of their family members. But a powerful bonding between two rudalis who join hands with a host of sexually-exploited women can eventually gather enough potential to confront the hypocrisy surrounding the tyrannical social structure. The present paper focuses on how in a rotten world-order of rustic India tears can also be a thing for sale and how the oppressed women manage to manipulate chaotic situations for their advantage.
\end{abstract}

Keywords: Rudali, Rajput tyranny, hypocrisy, postcolonial subaltern, female bonding, subversion, quasispiritual experience

Shedding tears is said to be a weakness of women who can at once manipulate their crying image to their advantage. While a crying man is an "embarrassment", the image of a crying woman is "usual". A crying woman earns the sympathies of those around her because she is 'vulnerable' and is in need of the support of man. The image of a crying woman thus reinforces the image of man as a protector. But what if the implication of the image is turned upside down? Mahasweta Devi, who is not only a progressive and radical writer but a passionate social activist fighting for the rights of tribals and the "lower-caste" people, consciously avoids such stereotypes in her writings. In her most famous works, there is little that can be called romantic. She strips literature of its ornaments and shows the skeleton-like bare structure of the society debunking all myths.

The story of "Rudali," whose film adaptation is more well-known to wider Indian people than the original story, is a fictional work whose realistic characterization revolves around the lives of two insolvent women. This paper will be restricted to the story, and try to unearth the suggestive connotations interspersed in between lines. In the story, Sanichari is a "Ganju" woman residing in a certain village called Tahad somewhere in Chhotanagpur. Her husband died-it was during British rule-when her only son Budhua was six years old. She was unable to shed tears at the demise of her mother-in-law, and even at the death of her husband. The apparent absurdity of the incident sets in motion the paradox which the story gradually unfolds. The abject situation of extreme poverty which questions the very possibility of survival renders the shedding of tears a luxury. Sanichari works in the Rajput maliks' houses or agricultural fiends, and manages to live on meagre meal. Budhua was married but met his father's fate, that is, he died a premature death.

(c) AesthetixMS 2016. This Open Access article is published under a Creative Commons Attribution Non-Commercial 4.0 International License (http://creativecommons.org/licenses/by-nc/4.o/), which permits non-commercial re-use, distribution, and reproduction in any medium, provided the original work is properly cited. For citation use the DOI. For commercial re-use, please contact aesthetixms@gmail.com. 
The son of Budhua ran away from the house. Budhua's wife, maddened rather by hunger than by grief, left the house only to become a "randi" at the red-light area of Tohri. While the immediate thought is directed to the mitigation of hunger, other thoughts-however ethical they might seem-are bound to be disregarded. Sanichari too concentrates on her work as labourer to make ends meet.

Sanichari's sudden encounter with Bikhni, her lost childhood companion, alters the ways of her life. Bikhni is an industrious lady and possesses a greater self-esteem than Sanichari. She "managed four cows, and two she-goats" and "fed the whole village on dahi-chivda-gur after taking a loan from the mahajan" on the eve of her son's marriage (p. 2o). But her son proved to be an ungrateful rogue-when the mahajan claimed Bikhni's house by way of repayment he took possession of the cows and settled in his in-law's house. Frustrated by the unexpected incident, Bikhni sold her two goats and stealthily left the village. The meeting of the two long-lost friends sets their lives on new course. On the advice of Dulan, a shrewd person in the village of Tahad, the two elderly women start their journey as "rudalis" or professional mourners. Dulan explains to them:

Amongst us, when someone dies, we all mourn. Amongst the rich, family members are too busy trying to find keys to the safe. They forget all about tears. [...] They need rudalis to wail over the corpse. [...] In the household of the masters, whores weep for the dead. [...] The two of you go, wail, cry, accompany the corpse. You'll get money, rice. On the day of the kirya ceremony you'll get clothes and food. (p. 23)

Through the image of the rudalis, Mahasweta Devi has delineated a whole picture of the filthy village politics in the tribal and "lower-caste" inhabited area of Chhotanagpur. The invaders of the land, the Rajputs, were not only exploitative of the local people whom they subjugated, but corrupted themselves. Through the mouth of Dulan, Mahasweta Devi has related the political upheavals of the region thus: the Rajputs, who were at first the warriors in the army of the Raja of Chhotanagpur, "infiltrated this remote area of tribals, and from zamindars, gradually built themselves up to the status of jotedars and moneylenders and established themselves as the masters of the area" (p. 26). They suppressed the Kol rebellion which began in opposition of the Rajput tyranny. Even after cruelly putting down the uprising, they went on killing and oppressing the innocent tribals. The Raja, agitated by all these, sent the Rajput warriors to the Tahad region where they established their autocratic rule. "They have elephants, horses, livestock, illegitimate children, kept women, venereal disease and a philosophy that he who owns the gun owns the land" (p. 27). The Rajput maliks are the living embodiment of corruption-they have no respect or sympathy for their old parents either. As the story starkly depicts, they compete with each other in their enthusiasm to employ rudalis to mourn over the death of their parents. There is no expression of genuine grief, but only an ostentatious show of grief performed by the rudalis. Some of the maliks book the rudalis even before the death of their ailing parents.

In the absence of professional mourners-who happen to be prosperous prostitutes in big cities-to mourn for "the unmourned dead," Sanichari and Bikhni become famous in the rural area. They find no shame in their work because "through motherhood and widowhood they were tied to the moneylenders, while those people spent huge sums of money on death ceremonies, just to gain prestige. Let some of that money come into Sanichari's home” (p. 27)! Sanichari makes a list of mourning categories and fixes charges for each:

'Just for wailing, one kind of rate.'

'Wailing and rolling on the ground, five rupees, one sikka.' 
'Wailing, rolling on the ground and beating one's head, five rupees, two sikka.'

'Wailing and beating one's breast, accompanying the corpse to the cremation ground, rolling around on the ground there-for that the charge of six rupees.'

'At the kirya ceremony, we want a cloth, preferably a length of plain black cloth.' (p. 28)

The remote region Sanichari and Bikhni dwell in metaphorically represents the failed nation of India with its beguiled promises of "democracy," "justice" and "equality." It has nothing righteous and just to its core, but builds around the ideologies of the elite class whose wickedness and impiety it amply manifests. Standard historiography does not provide any account of the exploitations, hardships and struggles of the down-trodden people. Even after the independence of India, the so-called lower-caste and lower-class people, the tribals and ethnic minority communities continue to reside in darkness. They are deprived of their fundamental rights, like food, shelter and security. In the words of Pramod Nayar (2008), they are the "postcolonial subaltern" sections of Independent India (p. 99). As a spokesperson of the subjugated mass, Mahasweta Devi deciphered the metrics of oppression and exploitation of these defenceless people. She wrote in the introduction to her short story anthology Srestha Galpa (1984) that it is wrong to judge literature on the parlance of language, style and form as the formalist, structuralist and deconstructionist critics do, but literature should be evaluated in the context of history which it incisively engages with. The nuances of subaltern history are strongly perceived in the oeuvre of Mahasweta Devi; the people in the margins of the nation-state predominate her fictional works.

The story "Rudali" does not only engage with the issue of exploitation of the lower-class people, but specifically addresses the gender-question. The women of the oppressed classes suffer not only from their socio-economic disadvantages, but also because of their gender. The raceclass-caste-gender nexus makes the condition of women difficult in rural Indian society. The "difference" feminism or third world feminism which registers its objections against the first world feminism derives much from Chandra Mohanty's (1988) description of the women in former European colonies (especially India) who are homogenously represented as third world woman. The prevailing dominance of upper-class, educated, white women who control the discourse of the first world feminism renders the representation of the third world women's condition inappropriate. The difference between them is seldom taken into account- for instance, Indian women's suffering resulting from their race, ethnicity, caste, religion, and so on. As such Western feminism has been accused of growing into a hegemonic discourse which is as exclusive as patriarchal discourse. The rise of "second wave" Indian feminism in 1970s, according to Alka Kurian (2005), raised greater consciousness among the women of their rights than in the earlier period of India's struggles for Independence. But the ramifications of this awarenessgrowing were limited to the metropolitan cities while the women in the rural areas or those belonging to lower class, "lower caste" or minority communities continued to remain in shadows. Mahasweta Devi's stories retrieve the invisible women and their muted voices from the peripheries of Indian society. The story "Rudali" brings into light the plight of women belonging to different segments in a rural society: the rudalis, the prostitutes and the upper-class housewives. Even the prostitutes are of two types: those kept-women (mistresses) who reside in the mansions of the Rajput maliks, and those who rot in brothels at Tohri. The story relates how the "whores" in the houses of these people are often forced to leave their havelis and settle in the red-light areas as "randis" in their old age. As Dulan caustically narrates the incidents in the Rajput households, the reader comes to know how the daughters of such kept-women also meet the same fate as their mothers: 
'[...] What vicious bastards the lot are! The worst is Gambhir Singh. He kept a whore, has a daughter by her. As long as the whore was alive, he kept the child in comfort. When the mother died, he told the girl: "A whore's daughter is a whore-practise your profession and support yourself."

$[\ldots]$

'That girl is now rotting in Tohri, in the randi bazaar. From a five-rupee whore, she's down to a five-paise whore. [...]' (p. 24)

What is interesting about "Rudali" is that here the story does not depict the crying women as week or in need of men's support. Ironically, the story is a penetrating scrutiny of how the traditional image of a crying woman can be subverted. Here the crying women do not cry at their own destitution, but their tears rescue the men from their shame. The rudalis cry to save the "honour" of upper-class men who employ the women to mourn over the death of their near and dear ones because they are incapable of shedding tears. Heartlessness added by hypocrisy of the Rajput maliks is evident when the reader sees the funeral being arranged before the demise of the man whose death is to be mourned over. In the words of the omniscient Dulan:

'Nathuni is such a worthy son that he's isolated her [his mother] in a single room at the far end of the compound. Aside from tying a goat to her bed, he hasn't bothered with any treatment. No hakim, no kabiraj, no doctor. No herbal remedies, no medicine, no injections. She's still alive. Meanwhile, he's stocking up on sandalwood and sal wood for a sensational funeral pyre. Bales of cloth are arriving, for distribution at the kirya ceremony. He's preparing to feed Brahmins and purchased loads of ghee, sugar, dal, flour. [...]' (p. 30)

Surprisingly enough, the hypocrisy afflicted the women of the Rajput household too. The middle wife of Nathuni paid Sanichari an advance to gather the rudalis for her rich father in his deathbed. Her aim is to compete with her husband's exhibition of rudalis and the lavish kriya ceremony on his mother's death.

The story, on the other hand, underscores the advantages of a powerful female bonding existing between two impoverished women. Both Sanichari and Bikhni mutually support each other-while Sanichari provides shelter to Bikhni, the latter manages the household in which she is especially adept. Sanichari becomes a rudali at the advice of Dulan while Bikhni goes to the redlight area of Tohri to gather the prostitutes to perform at the death of the Rajput maliks. For a moment, discord falls in the flow of the story when Bikhni goes to the marriage of a distant relative (apparently, in order to show her son how she has been managing well without his support), and dies of asthma. When Sanichari hears the news, she is overcome by a strange feeling: "What did she feel? Grief? No, not grief, fear. Her husband had died, her son had died, her grandson had left, her daughter-in-law had run away-there had always been grief in her life" (p. 42). Sanichari is grasped by "fear" because the death of Bikhni would affect "her livelihood, her profession." In her old age, she found a companion, set up a new home, and began a profession which had been flourishing. She is worried about her future now. But she does not cry: "Money, rice, now clothes-without getting these in return tears are a useless luxury" (p. 43). She has understood the cost of crying. Even though she loved Bikhni, Sanichari is unable to shed tears for her unexpected death.

At the end of the story, Sanichari goes to Tohri herself and asks the "randis"-including her daughter-in-law - to gather at the death of Gambhir Singh. She provokes Gulbadan, Gambhir Singh's illegitimate daughter whom he banished from his house: "by wailing for him and taking money you'll be rubbing salt in their wounds" (p. 45). Her obvious target is the lewd nephew of 
Gambhir Singh who tried to seduce Gulbadan. The story reaches its climax when nearly a hundred rudalis come to mourn over the death of Gambhir Singh. His nephew and gomastha stand grief-stricken not because of the malik's death, but because of the thought of payment:

The randi rudalis surrounded his [Gambhir Singh's] swollen corpse and started wailing, hitting their heads on the ground. The gomastha began to weep tears of sorrow. Nothing will be left! Cunning Sanichari! Hitting their heads meant they had to be paid double! He and the nephew were reduced to helpless onlookers. (p. 45)

The nephew and the gomastha must bear the pain of losing the meagre amount Gambhir Singh has left for them. They can neither evict the rudalis nor forbid them to hit their heads because it is a matter of "prestige." The maliks now fall into their own traps and learn to shed tears of grief.

The story "Rudali" has the subtle structure of a quasi-spiritual experience. The crying women perform the function of mourning on behalf of the malik-mahajans. Thus, in a way, the rudalis purge the filthy hearts of these men. This spiritual dimension of the story makes it an important postcolonial text; as Pramod Nayar (2008) cites, Western feminism fails to comprehend the spiritual potential of postcolonial feminism. According to postcolonial feminist writers and thinkers, "the spiritual constitutes an important component of women's lives, and spirituality can be a means of self-empowerment too" (p. 114). This spiritual aspect of women's lives function mostly in ethnic and rural communities. Mahasweta Devi's story "Rudali" illustrates the quasispiritual dimension of the rudalis' profession which empowers the women and ruins the arrogant Rajput men.

\section{Bibliography}

Kurian, A. (2005). "Feminism and the developing world." The Routledge companion to feminism and postfeminism (pp. 54-64). Ed. Sarah Gamble. London: Routledge.

Mahasweta Devi. (2003). "Rudali." (A. Katyal, Trans.). In Urvashi Butalia (Ed.), Katha: Stories by Indian women (pp. 16-45). New Delhi: Stanza.

Mahasweta Devi. (1984). Srestha galpa (Best stories). Kolkata: Dey’s Publishing.

Mohanty, C. T. (1988). "Under western eyes: Feminist scholarship and colonial discourses." Feminist Review 30, 61-88. JSTOR. Retrieved Aug. 25, 2014, from http://www.jstor.org/stable/1395054

Nayar, P. K. (2008). Postcolonial literature: An introduction. Hyderabad: Pearson.

Author Profile:

Saikat Guha is a doctoral researcher at the Department of English, Cooch Behar Panchanan Barma University, West Bengal. He obtained his MPhil (2014) from the Department of English, University of North Bengal and PG Diploma in Folklore and Culture Studies (2015) from IGNOU (Siliguri Regional Centre). He was a guest lecturer in English at a general degree college. His articles appeared in a number of prestigious journals including Muse India, Rupkatha, The Apollonian, Singularities, Rock-Pebbles, New Academia, Polyphony, Dialogue, New Fiction Journal, Heteroglossia, and in twelve edited volumes. He co-edited two books, viz., Reading Literature through Feminist Lens and Postcolonial Approaches to Literature, both published by AuthorsPress 
(New Delhi) in 2015. His areas of interest include poetry, Indian literature, short story, postcolonialism, feminism, cultural studies and Northeast India. He is currently editing an academic book on Indian short stories. He can be reached at mmm.saikatguha@gmail.com . 